\title{
Spatial distribution and development of educational institutions in different historical periods: a Hungarian case study
}

\author{
Gyula Dézsi, Gábor Kozma*, Károly Teperics
}

University of Debrecen, Hungary

\begin{abstract}
The present paper studies the spatial distribution of elementary and secondary schools in a particular Hungarian settlement, Debrecen, the second largest city of country. In the course of the analysis factors influencing spatial distribution and the differences among certain historical periods are discussed. In the period before World War II location of elementary and secondary schools was influenced primarily by religion. Following World War II the increase of the number of inhabitants outside the city centre and especially the construction of new housing estates resulted regarding elementary schools in a significant decentralization. Urban plans prepared after World War II also regarded spatial decentralisation important in the case of the secondary schools, however, this was realized only in the case of vocational secondary schools and vocational schools. In the period after 1990 the appearance of new institute maintainers can be regarded as a determinant factor and this also resulted in decentralization.
\end{abstract}

Key Words: Geographical location, Debrecen, Religion, Elementary schools, Secondary schools.

Article Info: Received: August 29, 2014; Revised: October 27, 2014; Accepted: November 10, 2014; Online: November 30, 2014.

\section{Introduction}

Studies analysing urban structure prior to World War II (e.g. Chicago school) handled administration area uniformly and emphasized that these functions were located primarily in the city centre (Kaplan et al., 2009). From the 1960s researchers realized that this uniform view cannot be applied any more as the

\footnotetext{
* Corresponding author

Address: Department of Social Geography and Regional Development Planning, University of Debrecen, PO box 4032, Debrecen, Egyetem tér 1., Hungary.

Phone: +36-52-518-667 | Email: kozma.gabor@science.unideb.hu
} 
location of administration areas within the town is differentiated from two aspects. On the one hand, the different institutional functions (e.g. public administration, retail trade, culture, education, financial life) require different demands therefore their spatial structure within the town is also different (Heinritz - Lichtenberger, 1984).

On the other hand, researchers also revealed that significant differences are found in the case of a particular function as well in the spatial distribution of different level (elementary, secondary and higher) institutions. In the case of the research belonging to this latter group it is a significant problem that the focus was primarily on higher level institutions meeting generally regional demands pointing beyond the settlement (general analysis: Csapó, 2005; Grigorescu et al., 2012; Simion - Nistor, 2012; trade - Pacione, 2009; education: Makkai - Gyüre, 2012, culture: Trócsányi, 2011) while little attention was paid on institutions for elementary and secondary service (a sole exception is trade - Sikos, 2000; Charles - Kerry, 2005; O'Dwyer - Coveney, 2006; Cheng et al., 2007).

Considering the above, the present paper studies the spatial distribution of elementary and secondary educational institutions in a particular settlement, Debrecen, the second largest city of Hungary. The settlement is located in the eastern part of Hungary and is regarded to be one of the largest educational centres of the country. In the course of the analysis factors influencing spatial distribution and the differences among certain historical ages (prior to World War II, period between 1945 and 1990, after 1990) are discussed.

\section{Methods and materials}

The analysis covers the built-up area of Debrecen and excludes the more distant suburbs. In the course of the study the historical city centre that was developed by the end of the 1700s and the less built-up areas surrounding it were separated (Figure 1). Besides, only the schools educating on the basis of normal curriculum were involved in the study, institutes providing various special trainings (e.g. schools for short sighted, deaf and for handicapped children) were not studied. In the new millennium it is frequent that vocational schools have grammar school trainings as well but these were regarded to be vocational school in the course of categorization. In the course of the research maps of Debrecen from different time periods, monographs on the history of educational institutes, statistics of the local government and town plans were also used.

\section{Period before World War II}

Location of the elementary and secondary educational institutions at the end of the 1930s (Figure 1) was influenced by several factors. The most important role was that of religion as it was determinative in education at that age since churches - if they had a chance - tried to establish their schools near their church: this is reflected by the location of the Evangelical elementary school (1) and that of the Greek Catholic elementary school (2) regarding smaller religions.

Effects of the three religions important in the time period between the two 


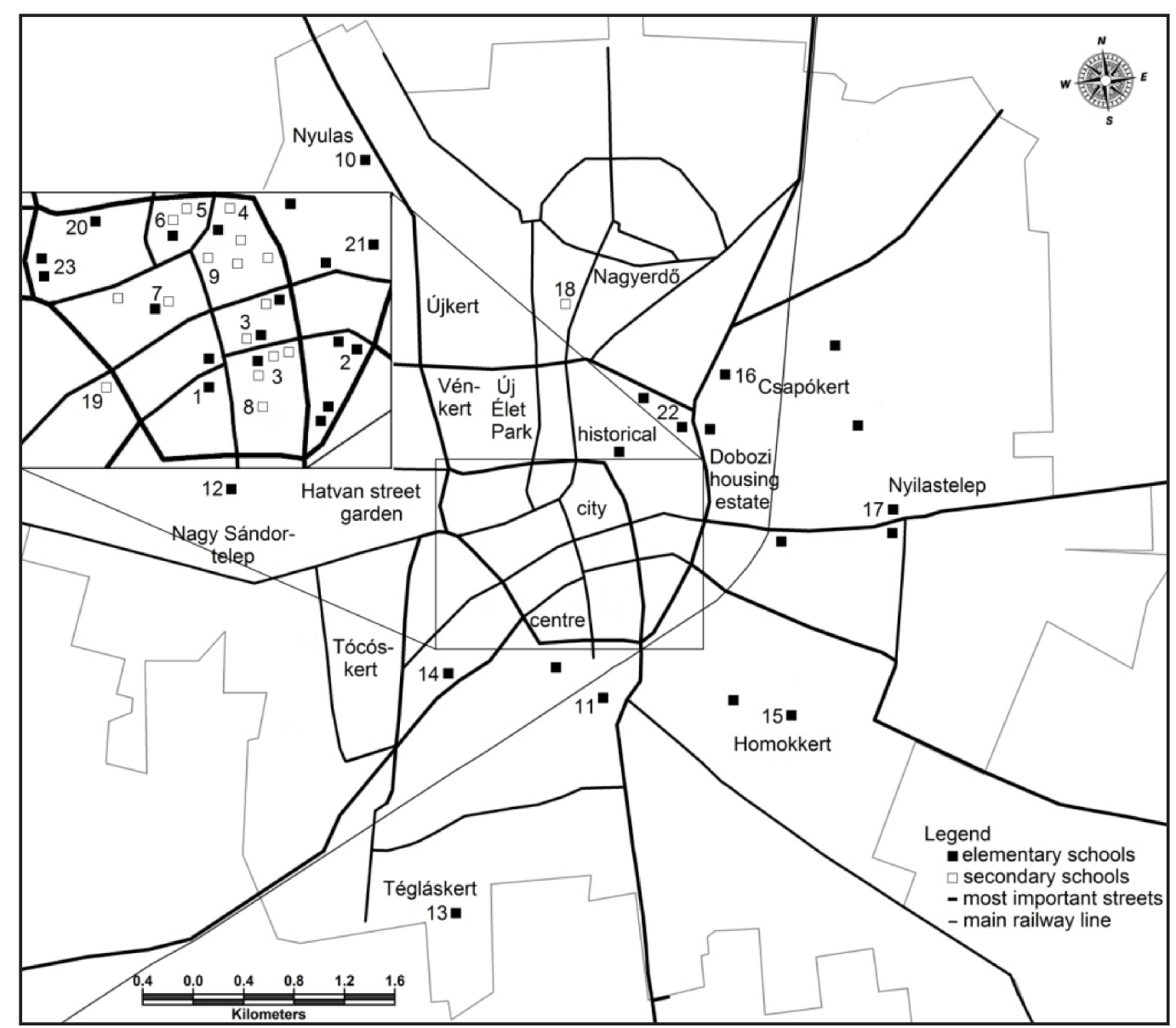

Figure 1. Most important urban districts in Debrecen and geographical location of elementary and secondary schools in Debrecen in 1939

Source: own work

world wars can be detected clearly in the location of schools. Considering Roman Catholic religion this can be explained by the opposition towards Roman Catholics in Debrecen as the capital of Calvinism and it gave permission to their settlement only when the national assembly in $1714 / 1715$ registered the town in among free royal cities with the condition of permission for Roman Catholics to settle (Pianovszky, 1931). Considering this, it is no wonder that Catholic educational institutes were located as near the Saint Anna church built in the middle of the 18th century as possible. As a result a significant educational centre (3) developed in the south-eastern part of city centre by the 1930s including elementary schools, a grammar school and a secondary school of commerce together with a girl's teachers' training institute. Grade of concentration is shown by the fact that outside this block only four small Roman Catholic elementary schools were operated in the city at the end of the 1930s (see later).

The Reformed religion had much more significant historical traditions in Debrecen and it operated $50 \%$ of the elementary schools of the city that were located mainly in the historical city centre and partly in the eastern and southeastern part of the city well scattered spatially. Some kind of concentration was detected in the location of the secondary schools operated by the Reformed 
Church: three out of the four institutes, Grammar School of the Reformed College of Debrecen (4), civil boy school of the Reformed College, Teachers' Training Institute (5) and Lyceum of the Reformed College of Debrecen (6) were operated near the cultic institutes of the Reformed Church in Debrecen. Third major religion of the time period between the two world wars was the Judaism followers of which lived primarily in the western part of the city centre It comes no surprise that three of the four schools of Jews (Jew Grammar School, Orthodox and status quo ante Israelite elementary schools) were found in this part of the city (7), however the fourth, Israelite civil girl school was also associated with the religion as it was located in the neighbourhood of the synagogue (8) near the railway station.

The other, much less significant influencing factor was professional connections that were important mostly for the secondary schools: schools of commerce (Boy and Girl Four Year School of Higher Commerce in Debrecen: 9) were operated near the headquarters of the Trader Association of Debrecen.

Considering the spatial concentration of educational institutes the historical centre had significant role at the end of the 1930s. Regarding elementary schools 21 out of 37 (Table 1) were operated in the city centre (this meant around 57\%) while regarding the number of population this ratio was only $45 \%$. Further problem was presented by the fact that the majority of the educational institutes outside the city centre were located in the eastern part of the city for a long time. As a result of this the distance between the schools and the home of school-age children was very large and for this reason many parents do not let their children go to school especially at the time of winter and wet periods.

The problem was known by the leadership of the city (Bendák, 1940) therefore several state elementary schools were established in the 1920s in less covered areas, among which Nyulas (10), Mikepércsi street (11), Köntösgát street (12) and Tégláskert (13) can be mentioned. The main reason was to decrease the concentration of the reformed schools in the city centre and in the

Table 1. Number and concentration in the city centre of the elementary and secondary educational institutes between the end of the 1930s and the academic year 2012/2013 (in the case of elementary schools not only the centre of the institute but all of the buildings are regarded for several years, the number of institutes in the city centre is in brackets)

\begin{tabular}{|c|c|c|c|c|c|c|}
\hline \multirow{2}{*}{} & \multicolumn{3}{|c|}{ elementary schools } & \multicolumn{2}{c|}{ grammar schools } & \multicolumn{2}{c|}{$\begin{array}{c}\text { vocational secondary } \\
\text { and vocational schools }\end{array}$} \\
\cline { 2 - 7 } & A & B & A & B & A & B \\
\hline $1939 / 40$ & 37 & $21(56.8)$ & 11 & $10(90.9)$ & 6 & $5(83.3)$ \\
\hline $1957 / 58$ & 43 & $21(48.8)$ & 7 & $7(100.0)$ & 8 & $6(75.0)$ \\
\hline $1969 / 70$ & 40 & $19(47.5)$ & 6 & $6(100.0)$ & 11 & $6(54.5)$ \\
\hline $1979 / 80$ & 43 & $18(41.9)$ & 6 & $6(100.0)$ & 12 & $5(41.7)$ \\
\hline $1990 / 91$ & 36 & $10(27.8)$ & 8 & $7(87.5)$ & 14 & $5(35.7)$ \\
\hline $2012 / 13$ & 32 & $9(28.1)$ & 11 & $7(63.6)$ & 24 & $5(20.8)$ \\
\hline
\end{tabular}

Source: Official data of the Mayor's Office in Debrecen city of county rank, Bendák, 1940 
eastern part of the city. In the same decade the Roman Catholic Church also had to establish a smaller school in each of the Szoboszlai street (14), the Homokkert (15), the Csapókert (16) and in the Nyilastelep (17) in order to easy the crowdedness of the elementary schools in city centre and to approach its followers (in the case of the two latter an important factor was the closeness of a Roman Catholic Church and the location of the school in the Nyilastelep was also influenced by the fact that the workers were mostly Catholic in the Railway Repair Factory).

Although the mentioned new institutes improved the situation slightly (the ratio of $57 \%$ mentioned before was obtained in this way), however, at the end of the 1930s still numerous children went to the elementary school of the Reformed Church located in the northwest part of the city centre who often had to walk 3-4 kilometres daily.

Even more concentrated were the secondary educational institutes: only two, Practice Grammar School of the Royal Hungarian Teachers' Training Institute (18) and Royal Hungarian State Timber and Metal Industrial Vocational School (19) out of the 17 secondary schools of the city were located outside the city centre (the latter one is placed on the other side of the road bordering the city centre). High number of grammar schools (especially as compared to the data of 1957/58) can be explained by that they also included the civil schools providing lower level of education (all three great churches - Reformed, Roman Catholic, Israelite - had such), on the other hand most churches separated girls and boys and established separate schools for them.

\section{Period between World War II and 1990}

Socialisation of education was a fundamental factor in the time period between World War II and 1990 in the framework of which the institutes owned formerly by the churches were overtaken by the state (actual management was the task of local councils). This process was completed in Debrecen as well therefore only three institutes were operated by churches in the city (one Reformed grammar school and one Roman Catholic elementary and grammar schools each). This fact resulted in that the distribution of educational institutes in the city was determined by the urban plans prepared by the urban planners and accepted by the city leadership.

Following World War II in the decades of 1940s and 1950s the most important aim of the country was the development of heavy industry situated in axis crossing Hungary from SW towards (Pet - Szakács, 1985). Debrecen, as a city primarily relying on agriculture and situating outside of this axis, was left out of industrial developments, and consequently, there were no large-scale investments in the city. As a result only slight changes occurred in the spatial distribution of educational institutes of Debrecen in these decades. Number of elementary schools was slightly increased (up to 43) and the dominance of the historical city centre ceased (Figure 2). Number of grammar schools decreased as a result of the closure of civil schools mentioned above. In the case of the vocational schools and vocational secondary schools the effect of the economy intensified: in order to meet the demand for professionals of the investments that just got 


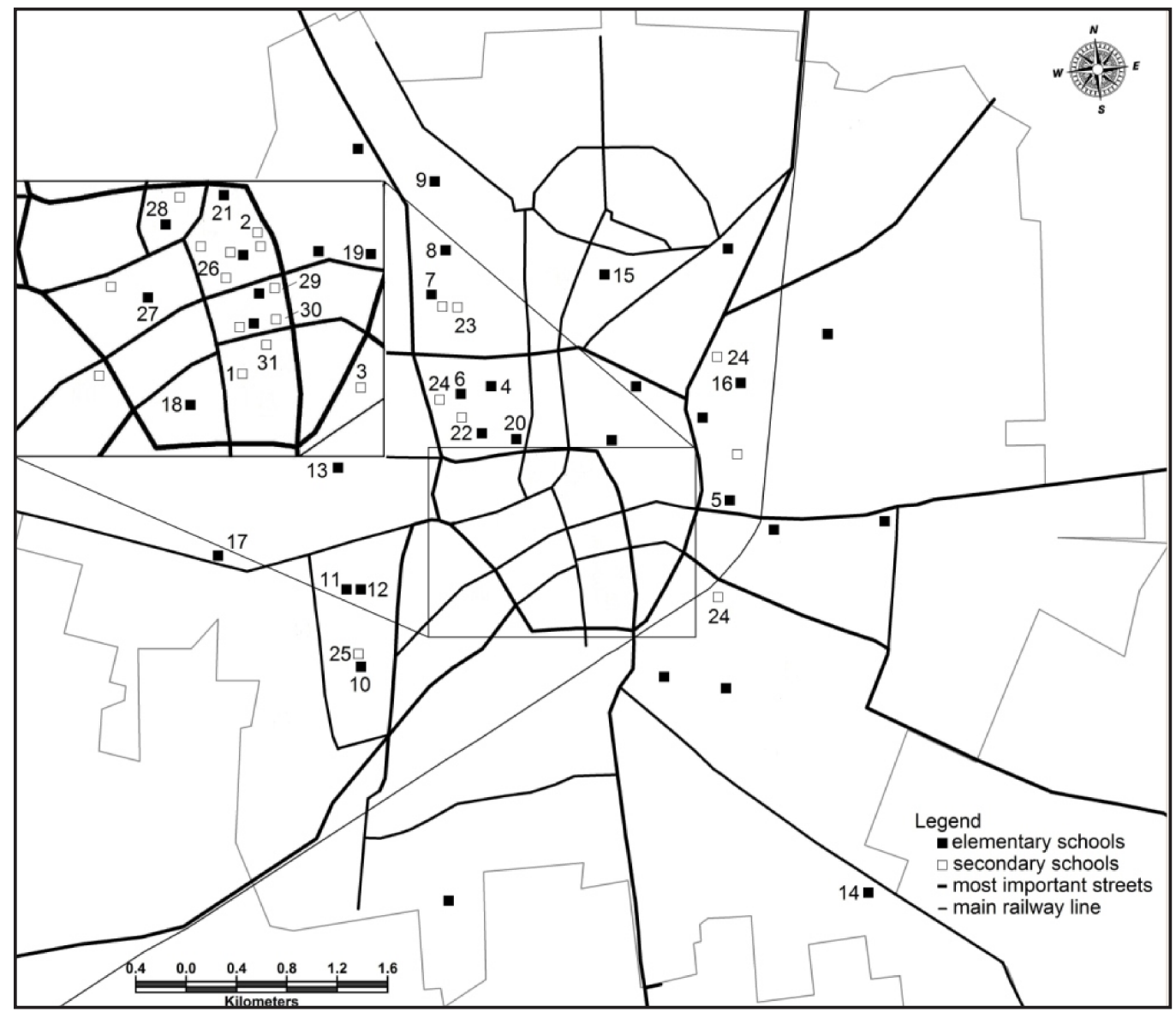

Figure 2. Geographical location of elementary and secondary schools in Debrecen in 1990

Source: own work

underway and of the two factories (pharmaceutical factory that can be regarded as the sole new factory at that time and tobacco factory that had a rich tradition) of the city three new secondary schools (technical schools in the terminology of that time) were established: building industry technical school (1), chemical industry technical school (2), tobacco industry technical schools (3). In the spatial distribution of the institutes, however, hardly any changes appeared, concentration in the city centre remained high.

From the first half of the 1960s increasing emphasis was on the development of areas outside the heavy industrial axis and this influenced the development of Debrecen and the situation of elementary and secondary education as well. Urban plans on the one hand contained the establishment of several new industrial factories and the extension of the existing ones, on the other hand partly as a result of location of industry - significant increase of the city's population was expected: According to the General Urban Plan constructed in 1961 the number of the inhabitants in the built-up area of the city increased from 105,000 people to 160,000 people over 25 years (Niklai, 1962) while the General Urban Plan of 1969 stated that the number of inhabitants in the city would reach 300,000 people by 2000 (Szokolai, 1969). 
Development of the industry required the extension of the number of available professionals, i.e. the establishment of new secondary schools (primarily vocational secondary and vocational schools) was necessary: the General Urban Plan of 1969 involved the construction of 183 new classrooms apart from the already existing 85 (Szokolai, 1969). Increasing population made the extension of elementary education and the building of new elementary schools inevitable: the General Urban Plan of 1969 calculated with almost 1,200 new classrooms until 2000.

Regarding the location of the new institutes in the city the plans emphasized the importance of decentralization. In relation to the increase of population the plans introduced the term "neighbouring units" that meant residential areas bordered by busy roads and emphasized the provision of elementary public institutions (including elementary schools) within these areas (the General Urban Plan of 1961 defined 31 such neighbouring units and the construction of 315 new elementary school classrooms was necessary in 22 units (Niklai, 1962). Considering secondary schools documents stated that the actual central location is not healthy causing overcrowding in transport therefore it is not sustainable in the long-term and the reduction of the concentration in the city centre is necessary.

According to the stated ideas significant measures were made from the middle of the 1960s in order to decentralize the elementary and secondary educational network (Figure 2). In the case of elementary schools this included two areas: new, modern institutes were established on the one hand in the new housing estates: 1960s: Új Élet Park (4), Dobozi housing estate (5), 1970s: Vénkert housing estate (6), 1980s: Újkert housing estate (7, 8, 9), Tócóskert (10, $11,12)$. On the other hand as a result of investments new elementary schools were built in the outer areas of the city as well that were poorly supplied, however, their population increased significantly partly due to the construction of owner-occupied blocks: Hatvan street garden (13), Homokkert (14), Nagyerdo (15), parts of the Csapókert close to the city centre (16), Nagy Sándortelep (17).

In the case of the elementary schools of the historical city centre two processes could be observed in the period between the 1950s and 1990. On the one hand, numerous institutes were closed (e.g. Figure 1-1, 20, 21, 22, 23) that can be explained by two factors. The most of the related schools were constructed before World War II and due to their limitations they were less suitable for modernizing, they could not meet the increased demands. Besides, less-and-less children applied for these institutes due to their out-of-date conditions and the ageing of the population in the city centre. This also supported the closure of $t$ he institutes.

On the other hand, a few new elementary schools were established in the historical city centre (Figure 2): Fazekas Mihály (18) and Benedek Elek (19) Elementary Schools due to their location attracted children from the surrounding housing estates beside those living in the city centre. The elementary school on Hajó street (20) attracted children from the housing estate intruding into the city centre while the elementary school on the Hunyadi street (21) operated as the institute for practice of the Teachers' Training College next to it. 
Considering the spatial aspects of extension of secondary schools, two tendencies can be observed: on the one hand, as housing estates were constructed several secondary schools mostly general vocational secondary schools, for example vocational secondary school for trade and catering industry (22) and medical vocational secondary school (23) were established. On the other hand institutes related closer to industry (primarily vocational schools) were built near the larger industrial sites and factories (24) as practice for students was easier to complete.

In the case of grammar schools the dominance of the historical city centre remained: the first grammar school outside the city centre was opened in the Tócóskert (25) in the 1980s the other grammar school, Ady Grammar School (26) opened in the decade in the city was established in the city centre (the location was determined by professional connections as one of the main specializations of the school was drama therefore closeness to the Csokonai Theatre was an important factor).

\section{The period after 1990}

Basically two factors were behind the processes in elementary and secondary education after the regime change. Decreasing of the number of children started at city level and continued in the city centre resulting in the closure of further elementary institutes (Figure 2). When studying the process, however, a new element was that it was not concentrated entirely in the city centre (e.g. elementary school on Simonffy street: 27) but it appeared in housing estates as well (e.g. Újkert Elementary School: 7, 9; Tócóskert Elementary School: 11).

On the other hand, broading of the sphere of maintainers was also observable and this fact also influenced spatial distribution. Regarding new maintainers, churches were the most important ones. Churches think that increasing their role in the society can be achieved partly by strengthening their educational activity. As a result the Churches that already had important role in the educational life in Debrecen prior to 1945 targeted the recapture of their former institutes (or at least part of them). The phenomenon could be detected in the case of elementary schools as well (Figure 2), for example the Reformed Church regained the school on $\mathrm{F}$ vészkert street (28), however, spatial distribution was influence much more by the regaining of the buildings of secondary schools, Practice Grammar School of the Kossuth Lajos University (29), Tóth Árpád Grammar School (30), Csokonai Grammar School (31).

Leadership of the city considered the further operation of these schools important and this was only possible with the provision of new locations (Figure 3): in the case of the Tóth Árpád Grammar School a new building was constructed, the school remained, however, within the historical city centre (1). The Practice Grammar School of the Kossuth Lajos University moved into the renovated buildings of the former Bocskai barracks (2), while the Csokonai Grammar School occupied the buildings of a former elementary school in one of the housing estates (3). In the case of all three institutes the moving resulted in the significant improvement of the infrastructural conditions enabling education at a higher level. 


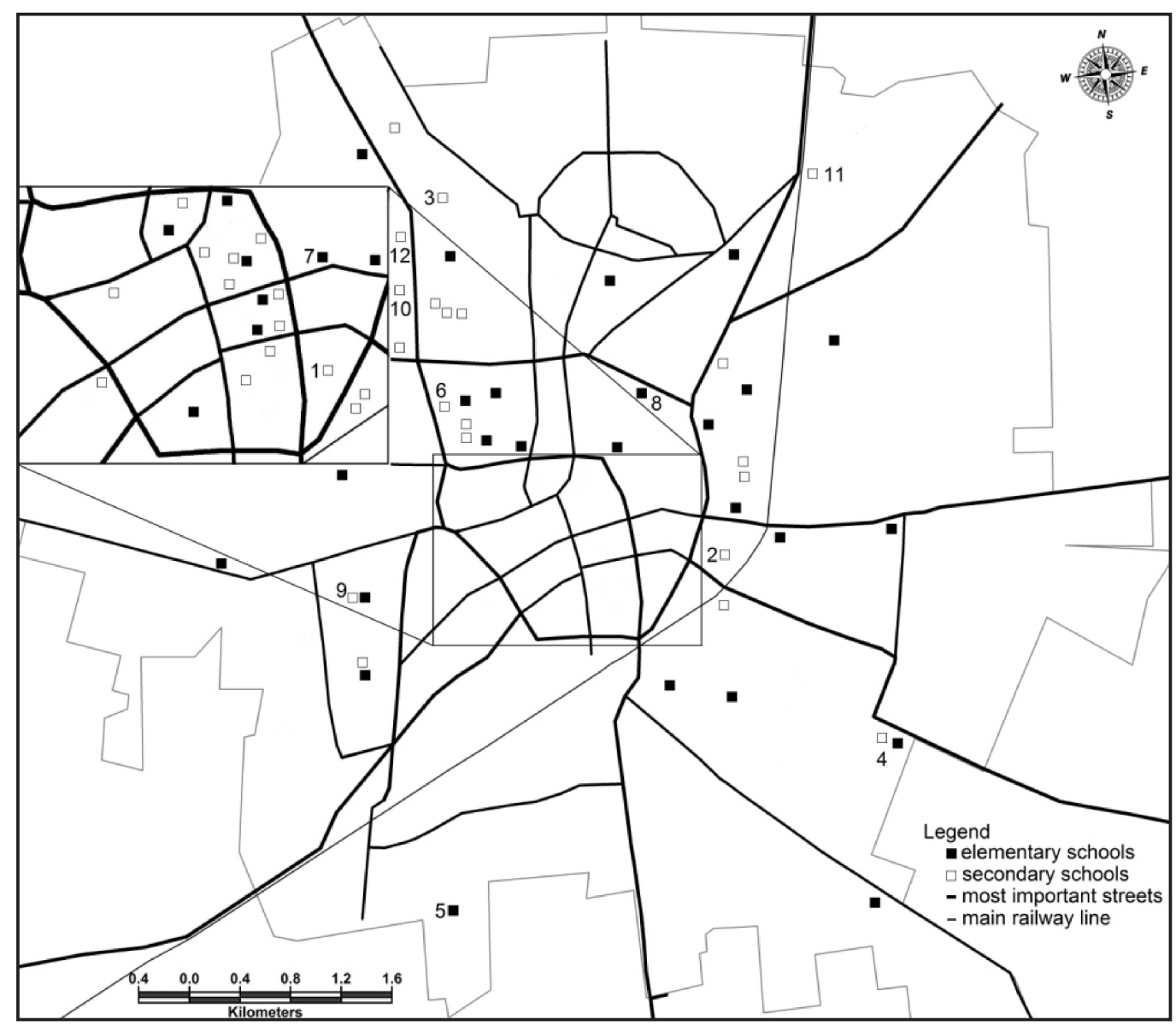

Figure 3. Geographical location of elementary and secondary schools in Debrecen in 2013

Source: own work

Regarding the less important or not traditional Churches three is worth mentioning in Debrecen: the Faith Church built an educational complex (4) including both elementary and secondary schools in a marginal area of the city. The Baptist Church took over the maintaining of several institutes that would have been otherwise closed by the city, Tégláskert Elementary School (5) and Diószegi Sámuel Secondary and Vocational School (6). The third church is the Greek Catholic that taken over the management of the Bányai Júlia Elementary School (7) in 2012 (in the selection of the school the closeness of the Greek Catholic Church and church centre was probably important).

Besides Churches the other large group of new maintainers is composed of various foundations who establish their primarily secondary educational institutes (the sole exception is the elementary school managed by the Waldorf Foundation that is operated in the place of the elementary school in the city centre closed by the local government: 8 ) in order to meet the demands on the market (e.g. economic, informatic, arts and cosmetics). The schools are found dominantly in the outer part of the city basically due to the fact that the associated institutes found cheap properties in these areas where high level theoretical and practical training was possible. In this respect among other things Euro 
Vocational School and Vocational Secondary School (9), Vocational Secondary School of Economics of the DISCIMUS Foundation (10), Sirius Vocational Secondary School of Informatics and Economics (11) and Kleopátra Secondary School and Vocational School (12) can be mentioned.

\section{Conclusions}

The most important statements of the study can be summarized as follows. The location of elementary and secondary schools was influenced primarily by religion in the period before World War II, which fact, taking into account the important role of religion in the everyday life of people, was characteristic in Hungary, and in a smaller extent in other Central European countries as well. A special feature of Debrecen was the dominance of the reformed church (the city is very often called Calvinist Rome), and for this reason the more or less even distribution of primarily schools belonging to this religion could be observed, while in the case of other religions a more concentrated pattern could be observed. Although the local government made efforts to achieve a certain degree of decentralization, its activity was successful only in the case of elementary schools and a significant spatial concentration was characteristic in the case of secondary education. This latter fact is fundamentally in harmony with the model of concentric circles elaborated in the 1920s (Park, 1925), which indicates concentration in the city centre in case of higher-level services; at the same time, it is contrary to the multiple nuclei model drawn up by Harris and Ulman, primarily referring to the conditions before World War II (Harris - Ulman, 1945).

Following World War II (primarily after 1960) the increase of the number of inhabitants outside the city centre and especially the construction of new housing estates and block houses resulted regarding elementary schools in a significant decentralization and simultaneously the closure of a part of the elementary schools in the city centre (this phenomenon could be witnessed in other socialist countries as well). Urban plans prepared after World War II also regarded spatial decentralisation important in the case of the secondary schools, however, this was realized only in the case of vocational secondary schools and vocational schools, while considering spatial distribution professional connections had an important role. The location of the institutions in this period was even less aligned with various models than in earlier times, and due to the intention of using location close to the population, it is generally characteristic for institutes of higher education, mostly examined due to their proximity to the population, and partly the spatial concentration experienced on the peripheries of settlements (Lichtenberger, 1972) could not be really observed either.

In the period after 1990 the appearance of new institute (churches, foundations) maintainers can be regarded as a factor determining the spatial structure of institutes (this fact could be witnessed in other former socialist countries as well). This also resulted in decentralization either directly (establishment of completely new institutes) or indirectly (replacement of the schools given back to the Church) and this process was greatest in the case of the vocational secondary and vocational schools. 


\section{References}

Bendák, Gy 1940, Debrecen népoktatása, in E Csobán (ed) Debrecen szabad királyi város és Hajdú vármegye, Vármegyei Szociográfiák Kiadóhivatala, Budapest, pp. 232-237.

Charles, CC \& Kerry, VD 2005, Store location in shopping centers: theory and estimates, Journal of Real Estate Research, vol. 27, no. 3, pp. 237-266.

Cheng, EWL, Li, H \& Yu, L 2007, A GIS approach to shopping mall location selection, Building and Environment, vol. 42, no. 2, pp. 884-892.

Csapó, T 2005, A magyar városok településmorfológiája, Savaria University Press, Szombathely.

Grigorescu, I, Mitrica, B, Kucsicsa, G, Popovici, EA, Dumitrascu, M \& Cuculici, R 2012, Post-communist land use changes related to urban sprawl in the Romanian metropolitan areas, Human Geographies - Journal of Studies and Research in Human Geography, vol. 6, no. 1, pp. 35-46.

Harris, CD \& Ulman, EL 1945, The Nature of City, Annals of the American Academy of Political and Social Sciences, vol. 242, no. 1, pp. 7-17.

Heinritz, G \& Lichtenberger, E 1984, Wien und München - Ein stadgeographischer Vergleich, Berichte zur deutschen Landeskunde, vol. 58, pp. 55-95.

Kaplan, D, Wheeler, JO \& Holloway, S 2009, Urban geography, John Wiley \& Son, Honboken.

Makkai, B \& Gyüre, J 2012, Coexistence of different social groups around one of the campuses of the University of Pécs, Revija za Geografijo, vol. 7, pp. 99-111.

Lichtenberger, E 1972, Die Wiener City. Bauplan und jüngste Entwicklungstendenzen, Mitteilungen der Österreichischen Geographischen Gesellschaft, vol. 114, no. 1, pp. 42-85.

Niklai, Á 1962, Város és városfejlesztés - Debrecen távlati fejlesztési terve, Debrecen Megyei Jogú Város Tanácsa, Debrecen.

O'Dwyer, LA \& Coveney J 2006, Scoping supermarket availability and accessibility by socio-economic status in Adelaide, Health promotion journal of Australia, vol. 17, no. 3, pp. 240-246.

Pacione, M 2009, Urban geography, Routledge, New York and London.

Park, RE, Burgess, EW \& McKenzie, RD 1925, The City, The University of Chicago Press, Chicago and London.

Peto, I \& Szakács, S 1985, A hazai gazdaság négy évtizedének története 1945-1985, I. Az újjáépités és a tervutasitásos irányítás idoszaka, Közgazdasági és Jogi Könyvkiadó, Budapest.

Pianovszky, K 1931, Debrecen sz. kir. város népoktatásának fejlodése, in E Csobán \& F Csurös (eds) Debrecen, Szabad királyi város, Debrecen, pp. 399-412.

Sikos, TT 2000, Marketingföldrajz, VÁTI, Budapest.

Szokolai, Ö 1969, Debrecen Megyei Jogú Város Általános Rendezési Terv - Ismertetés II, Debrecen Megyei Jogú Város Tanácsa, Debrecen.

Simion, G \& Nistor, C 2012, Spatial structure changes inside post-communist capital city of Bucharest, Human Geographies - Journal of Studies and Research in Human Geography, vol. 6 , no. 1 , pp. 79-89.

Trócsányi, A 2011, The spatial implication of urban renewal carried out by the EEC programmes in Pécs, Hungarian Geographical Bulletin, vol. 60, no. 3, pp. 261-284. 